\title{
TANGGUNG JAWAB HUKUM PERUSAHAAN TRANSPORTASI ONLINE DAN DRIVER ONLINE TERHADAP PENGGUNA ATAS PERALIHAN AKUN DRIVER ONLINE
}

\author{
Renni Sellyna Limbong, Roida Nababan, Lesson Sihotang \\ Fakultas Hukum, Universitas HKBP Nommensen \\ rennislimbong@gmail.com
}

\begin{abstract}
Abstrak
Penelitian ini bertujuan untuk mengetahui bentuk hubungan antara perusahaan transportasi online dengan driver online dan untuk mengetahui bagaimana tanggung jawab perusahaan transportasi online dengan driver online terhadap pengguna jasa akibat adanya peralihan kepemilikan akun. perjanjian kemitraan adalah bentuk umum suatu hubungan hukum antara satu pihak dengan pihak lainnya atas dasar hubungan kemitraan. Hasil penelitian ini menunjukkan bahwa adanya bentuk hubungan hukum antara perusahaan transportasi online dengan driver online yaitu ada perjanjian kemitraan dalam kedua belah pihak. Kesepakatan yang dilakukan oleh para pihak untuk bersama-sama tunduk pada perjanjian. pelaku usaha mempunya kewajiban pada pasal 19 UU No. 8 Tahun 1999. Driver online juga dapat diminta pertanggung jawaban jika merugikan pengguna jasa akibat memperalihkan akun kepemilikkannya tersebut dikategorikan dalam perbuatannya melawan hukum yang diatur dalam pasal 1365 KUHperdata.
\end{abstract}

Kata Kunci : Peralihan Akun, Driver Online, Operator (Perusahaan) Online, Konsumen

\begin{abstract}
This study aims to determine the relationship between online transportation companies and online drivers and to find out how the responsibilities of online transportation companies and online drivers are towards service users due to a transfer of account ownership. Online transportation companies are business actors that provide application services for transportation services used by service users (passengers) as consumers. The results of this study indicate that there is a partnership agreement in both parties. Result of the research showed that there was a relation between law and the company of the online transportation with online's driver it's partnership agreement in both parties. An agreement made by the parties to agree on the agreement submit to the agreement. Business actors have an obligation to article 19 of Law No. 8 of 1999 concerning Consumer Protection. And online drivers can also be held responsible if they harm the distiction users because their actions in transferring their ownership account are categorized as actions against the law as regulated in article 1365 of the Indonesian Criminal Code.
\end{abstract}

Keywords: Divert Account, Online Driver, Online Operator (Company) Information, Consumen 


\section{PATIK : JURNAL HUKUM Vol : 09 No. 2 April 2020, Hal 102 -113}

\section{Pendahuluan}

Pada saat pemesanan alat transportasi online, tidak jarang terdapat ketidaksesuaian informasi dalam aplikasi yang ditampilkan pada penumpang. Terdapat kasus dimana driver online menggunakan kendaraan yang berbeda dengan yang telah tercantum diaplikasi. Mobil atau sepeda motor yang digunakan untuk mengangkut penumpang memiliki plat nomor berbeda dengan plat nomor yang tercantum diaplikasi. Ada pula driver online yang identitasnya berbeda di aplikasi, dalam hal ini driver menggantikan orang lain untuk mengambil penumpang. Alasan yang digunakan driver saat diketahui tidak menggunakan kendaran yang sama pada aplikasi atau identitasnya berbeda dengan aplikasi, Driver terkadang beralasan mobilnya sedang di service atau sedang melalui proses perawatan, selain itu untuk identitas driver yang tidak sama mereka beralasan bahwa menggantikan ayah, teman atau kerabatnya untuk mengambil penumpang karena yang bersangkutan sedang sakit atau sedang dalam posisi tidak dapat mengambil penumpang.

Dan selain alasan tersebut ternyata pada saat ini terdapat fakta bahwa banyak akun driver online yang dialihkan dengan cara diperjual-belikan. Kegiatan peralihan akun pada dasarnya merupakan kegiatan yang dilarang oleh perusahaan dan tidak dibenarkan secara hukum, dalam hal ini akun pada dasarnya bukan merupakan suatu benda yang dapat dialihkan sesuka hati pada orang lain dengan cara diperjual-belikan.

Akun driver online merupakan milik pribadi dan khusus sehingga untuk penggunaannya juga tidak boleh digunakan oleh orang sembarangan yang bukan pemiliknya. Terjadinya peralihan kepemilikan akun driver online ini diakibatkan karena mulai sulitnya mendaftarkan diri menjadi mitra pengemudi/driver online dikarenakan adanya penerimaan jumlah driver online dibatasi.

Adanya pembatasan untuk penerimaan jumlah driver online, saat ini banyak driver online yang mengambil jalan pintas dengan membeli akun orang pemilik sebelumnya untuk digunakan mencari penumpang. Akun tersebut dijual dengan kisaran harga yang bermacam-macam. Dijejaring media sosial seperti facebook maupun langsung bertransaksi (tatap muka) dengan sipenjual dan sipembeli akun ojek online, terdapat beberapa grup juga seperti facebook dijadikan sebagai media untuk melakukan transaksi peralihan akun ojek online. Didalam satu grup terdapat lebih dari 14.500 anggota sebagian diantaranya menjual akun dan perlengkapan lainnya seperti helm, jaket, ATM, serta telepon genggam. Untuk mendapat akun ojek online pembeli harus membayar uang sebesar Rp 1 juta sampai Rp 1,5 juta kepada sipenjual atau yang mempunyai akun sebelumnya. ${ }^{1}$

Dengan adanya praktik peralihan akun driver online terdapat sebuah kasus dengan mengakibatkan kerugian terhadap pihak perusahaan ojek online maupun penumpang, Dengan melibatkan seorang driver online pengguna akun hasil jual-beli. Tujuan transportasi sebenarnya untuk mengantarkan penumpang ketempat tujuan dengan selamat tidak tercapai, pengaturan mengenai ojek online berbasis aplikasi ini sangat diperlukan demi terwujudnya kepastian hukum dan terlindunginya hak para pihak. Berdasarkan uraian diatas rumusan masalah dari penelitian ini adalah :

1. Bagaimanakah bentuk hubungan hukum antara perusahaan transportasi online dengan driver online?

2. Bagaimana tanggung jawab perusahaan transportasi online dan driver online terhadap pengguna jasa akibat adanya peralihan kepemilikan akun?

${ }^{1}$ Tribunnews,metropolitan, Marak Jual Beli Akun Ojek Online, Go- Jek Ditawar RP 1,5 Juta, https://www.tribunnews.com/metropolitan/2018/03/13/marak-jual-beli-akun-ojek-online-satu-akun-go-jekditawar-rp-15-juta?page=all (diakses 11 Februari 2020 pada pukul 21:30 Wib). 


\section{Tinjauan Pustaka}

Sebagaimana telah dijelaskan dimuka, perjanjian adalah salah satu sumber perikatan. Perjanjian melahirkan perikatan,yang menciptakan kewajiban pada salah satu atau lebih pihak dalam perjanjian. Kewajiban yang dibebankan pada debitur dalam perjanjian, memberikan hak pada pihak kreditor dalam perjanjian untuk menuntut pelaksanaan prestasi dalam perikatan yang lahir dari perjanjian tersebut. Pelaksanaan prestasi dalam perjanjian yang disepakati tersebut. Dalam hal debitor tidak melaksanakan perjanjian yang telah disepakati tersebut, maka kreditur berhak untuk menuntut pelaksanaan kembali perjanjian yang belum, tidak sepenuhnya atau tidak sama sekali dilaksanakan atau yang telah dilaksanakan secara bertentangan atau tidak sesuai dengan yang diperjanjikan, dengan atau tidak disertai dengan penggantian berupa bunga, kerugian dan biaya yang telah dikeluarkan oleh kreditur.

Menurut ketentuan pasal 1313 Kitab Undang Undang Hukum Perdata, perjanjian didefenisikan sebagai: "perjanjian adalah suatu perbuatan dengan mana satu orang atau lebih mengikatkan dirinya terhadap satu orang lain atau lebih". Jika diperhatikan secara seksama,rumusan yang diberikan dalam pasal 1313 BW tersebut ternyata menegaskan kembali bahwa perjanjian mengakibatkan seseorang mengikatkan dirinya terhadap orang lain. Ini berarti dari sebuah perjanjian lahirlah kewajiban atau prestasi dari satu atau lebih orang (pihak) kepada satu atau lebih orang (pihak) lainnya, yang berhak atas prestasi tersebut. Rumusan tersebut memberikan konsekuensi hukum bahwa dalam suatu perjanjian akan selalu ada dua pihak, dimana satu pihak adalah pihak yang wajib berprestasi (debitor) dan pihak lainnya adalah pihak yang berhak atas prestasi atas prestasi tersebut (kreditur). Masing masing pihak tersebut dapat terdiri dari satu orang atau lebih orang, bahkan berkembangnya ilmu hukum ,pihak tersebut dapat juga terdiri dari satu atau lebih badan hukum. ${ }^{2}$ Berdasarkan hal tersebut perjanjian dapat disimpulkan juga sebagai berikut: “ perjanjian adalah persetujuan dengan mana dua pihak atau lebih saling mengikatan diri untuk melaksanakan sesuatu hal yang bersifat kebendaan dibidang harta kekayaan".

Karena setiap perjanjian yang dibuat harus benar-benar dilaksanakan. Maka jika perjanjian tersebut tidak dilaksanakan, maka akan diategorikan sebagai perbuatan wanprestasi atau ingkar janji yang memberikan hak kepada pihak yang dirugikan untuk menuntut ganti rugi. Mengingat begitu penting dan begitu kuatnya kekuatan mengikat suatu perjanjian maka tidak sembarangan membuat perjanjian, ada syarat-syarat yang harus dipenuhi agar perjanjian menjadi sah dan mengikat para pihak.

Berdasarkan ketentuan hukum yang berlaku pasal 1320 Kitab Undang-UndangHukum Perdata, suatu perjanjian dinyatakan sah apabila telah memenuhi empat syarat komulatif (keempat-empatnya harus dipenuhi) yang terdpat dalam pasal tersebut, yaitu: Sepakat mereka yang mengikatkan dirinya; Kecakapan untuk membuat suatu perikatan; Suatu hal tertentu; Suatu sebab yang halal; Syarat pertama dan kedua dinamakan syarat subjektif, karena berkenaan dengan para subjek yang membuat perjanjian itu.Sedangkan syarat ketiga dan keempat dinamakan syarat objektif karena berkenaan dengan objek dalam perjanjian tersebut.

Dalam perjanjian konsensuil,kesepakatan yang dicapai oleh para pihak secara lisan, melalui ucapan saja telah mengikat para pihak. Ini berarti bahwa segera setelah para pihak menyatakan persetujuan atau kesepakatannya tentang hal hal yang mereka bicarakan, dan akan dilaksanakan maka kewajiban telah lahir pada pihak terhadap siapa yang telah berjanji untuk memberikan sesuatu, melakukan atau berbuat sesuatu atau untuk tidak melakukan atau berbuat sesuatu. Jika kita perhatikan rumusan dan pengertian yang telah

\footnotetext{
${ }^{2}$ Kartini Muljadi \& Gunawan Widjaya, 2003, Perikatan Yang Lahir Dari Perjanjian, Jakarta : PT Raja Grafindo Persada, hlm.91-92.
} 


\section{PATIK : JURNAL HUKUM Vol : 09 No. 2 April 2020, Hal 102 -113}

dijelaskan diatas, semua hal tersebut menunjukkan pada kita semu bahwa perjanjian dibuat dengan pengetahuan, dan kehendak bersama dari pada pihak, dan tujuan untuk menciptakan atau melahirkan kewajiban pada salah satu atau kedua belah pihak yang membuat perjanjian tersebut. Dengan demikian, sebagaimana telah disinggung perjanjian sebagai sumber perikatan berbeda dari sumber perikatan lain, yaitu UU, berdasarkan pada sifat kesukarelaan dari pihak yang berkewajiban untuk melakukan prestasi terhadap pihak lawan pihaknya dalam perikatan tersebut. Dalam perjanjian, pihak yang wajib melakukan suatu prestasi, dalam hal ini debitor dapat menentukan terlebih dahulu dengan menyesuaikan pada kemampuannya untuk memenuhi prestasi dan untuk menyelaraskan dengan hak (dan kewajiban) yang ada pada lawan pihaknya, apa kapan dan dimana dan bagaimana ia akan memenuhi prestasinya tersebut.

Dalam rangka menciptakan keseimbangan dan memelihara hak hak yang dimiliki oleh para pihak sebelum perjanjian yang dibuat menjadi perikatan yang mengikat bagi para pihak, oleh BW diberikan berbagai asas umum, yang merupakan pedoman atau patokan,serta menjadi batas atau rambu dalam mengatur dan membentuk perjanjian yang akan dibuat sehingga pada akhirnya akan menjadi perikatan yang berlaku pada pihak , yang dapat dipaksakan pelaksanakan atau pemenuhannya. Berikut ini dibahas asas asas umum hukum perjanjian yang diatur dalam Kitab Undang Undang Hukum Perdata. ${ }^{3}$

Asas Kebebasan Berkontrak dapat dianalisis dari ketentuan pasal 1338 ayat(1) KUH Perdata yang berbunyi "semua perjanjian yang dibuat secara sah berlaku sebagai undang-undang bagi mereka yang membuatnya". Berdasarkan Asas Kebebasan Berkontrak,maka orang pada asasnya dapat membuat perjanjian dengan isi yang bagaimanapun juga, asal tidak bertentangan dengan undang-undang, kesusilaan dan ketertiban umum. Dalam sistem terbuka hukum perjanjian atau asas kebebasan berkontrak yang penting adalah "semua perjanjian"(perjanjian dari macam apa saja), akan tetapi yang lebih penting lagi adalah bagian "mengikatnya" perjanjian sebagai Undangundang.Kebebasan Berkontrak merupakan asas yang sangat penting dalam hukum peranjian.Kebebasan ini adalah perwujudan dari kehendak bebas,pancaran dari Hak Asasi Manusia

Asas Konsensualisme merupakan asensial dari Hukum Perjanjian. Sepakat mereka yang mengikatkan diri telah dapat melahirkan Perjanjian.Asas Konsensualisme menentukan bahwa suatu perjanjian yang dibuatdua orang atau lebih telah mengikat sehingga telah melahirkan kewajiban bagi salah satu atau lebih pihak dalam perjanjian tersebut, segera setelah orang-orang tersebut mencapai kesepakatan,atau konsensus meskipun kesepakatan tersebut telah dicapai secara lisan semata-mata.Asas konsensualisme mempunyai arti yang terpenting,bahwa untuk melahirkan perjanjian cukup dengan sepakat saja dan bahwa perjanjian itu (dan perikatan yang ditimbukanl karenanya) sudah dilahirkan pada saat atau detik tercapainya konsensus. Pada detik tersebut perjanjian tersebut sudah sah mengikat, bukan pada detik-detik lain yang terkemudian atau yang sebelumnya.Asas ini ditemukan dalam pasal 1320 ayat (1) KUH Perdata dan dalam pasal $3120 \mathrm{KUH}$ Perdata ditemukan istilah "semua" menunjukkan bahwa setiap orang diberikan kesempatan untuk menyatakan keinginannya (Will) yang rasanya baik untuk menciptakan perjanjian. Asas ini sangat erat hubungannya dengan Asas Kebebasan Mengadakan Perjanjian.

Perjanjian sebagai suatu figur hukum harus mengandung kepastian hukum.Kepastian ini terungkap dari kekuatan mengikat perjanjian itu yaitu sebagai undang-undang bagi para pihak. Asas kepastian hukum merupakan asas bahwa hakim atau

\footnotetext{
${ }^{3}$ Kartini Muljadi, op cit, hlm.7-8 \& 14.
} 
pihak ketiga harus menghormati substansi kontrak yang dibuat para pihak, sebagai mana layaknya UU. Mereka tidak boleh melakukan intervensi terhadap substansi kontrak yang dibuat para pihak. Asas ini dapat disimpulkan dalam pasal 1338 ayat(1) BW yang berbunyi : "Perjanjian yang dibuat secara sah berlaku sebagai Undang Undang”.

Dalam bahasa hukumnya disebut goedetrow.Asas ini berkaitan dengan pelaksanaan suatu perjanjian. Mengenai asas itikad baik ini terdapat dalam pasal 1338 ayat (3) KUH Perdata yang menentukan"persetujuan-persetujuan harus dilaksanakan dengan itikad baik". Itikad baik dapat dibedakan dalam pengertian subjektif (penilaiannya terletak pada sikap dan tingkah laku) dan objektif (penilainnya terletak pada akal sehat dan keadilan).Itikad baik dari segi subjektif berarti kejujuran.Hal ini berhubungan erat dengan sikap batin seseorang pada saat membuat perjanjian. Itikad baik dalam segi objektif berarti kepatutan yang berhubungan dengan pelaksanaan perjanjian atau pemenuhan prestasi dan cara melaksanakan hakdan kewajiban haruslah mengindahkan norma-norma kepatutan dan kesusilaan itikat baik.

Asas ini merupakan asas pertama dalam hukum perjanjian yang pengaturannya dapat ditemukan dalam ketentuan pasal 1315 KUH Perdatya yang bunyinya" pada umumnya tak seorang pun dapat mengikatkan diri atas nama sendiri atau meminta ditetapkannya suatu janji selain untuk dirinya sendiri". Dari rumusan tersebut diketahui bahwa pada dasarnya suatu perjanjian dibuat oleh seseorang dalam kapasitasnya sebagai iadividu atau pribadi hanya dapat mengikat dan berlaku untuk dirinya sendiri. ${ }^{4}$

Transportasi diatur dalam Undang-undang No.22 Tahun 2009 Tentang Lalu Lintas dan Angkutan Jalan pasal 1 angka 10 menyatakan bahwa kendaraan bermotor umum adalah setiap kendaraan yang digunakan untuk angkutan barang dan/atau orang dengan dipungut biaya. Jadi Transportasi online adalah pelayanan jasa transportasi yang berbasis internet dalam setiap kegiatan transaksinya, mulai dari pemesanan, pemantauan jalur, pembayaran dan penilaian terhadap pelayanan jasa itu sendiri. Transportasi online salah satu bentuk dari penyelenggara lalu lintas dan angkutan jalan yang berjalan dengan mengikuti serta memanfaatkan perkembangan ilmu pengetahuan (teknologi).

Dengan adanya transportasi online, para penumpang kini tak perlu lagi menghampiri pangkalan ojek ataupun tak perlu lagi menunggu di pinggir jalan untuk mendapatkan taksi. Para penumpang juga tidak harus terlibat dalam tawar-menawar karena tarif yang sudah ditentukan berdasarkan jarak tempuh.

Merupakan hubungan hukum atas dasar perjanjian dari kontrak elektronik dimana dalam hal ini perusahaan transportasi online (perusahaan penyedia aplikasi) merupakan pihak pelaku usaha yang memberikan jasa aplikasi untuk jasa layanan transportasi yang digunakan oleh pengguna jasa (penumpang) selaku konsumen, jadi hubungan hukum antara pengguna jasa dengan perusahaan transportasi merupakan hubungan hukum antara konsumen dengan pelaku usaha. Menurut pasal 1 angka 2 Undang-undang No.8 Tahun 1999 Tentang Perlindungan Konsumen, disebutkan bahwa konsumen adalah setiap orang pemakai barang dan/atau jasa yang tersedia dalam masyaratkat, baik bagi kepentingan diri sendiri, keluarga, orang lain maupun makhluk hidup lain dan tidak untuk diperdagangkan. Pengguna jasa alat transportasi online dalam hal ini merupakan pihak konsumen yang menggunakan produk dari perusahaan transportasi, yaitu sebuah aplikasi untuk melakukan pemesenan jasa transportasi online. Sedangkan pada pasal 1 angka 3 UU No. 8 Tahun 1999 Tentang Perlindungan Konsumen, disebutkan bahwa pelaku usaha merupakan setiap orang perseorangan atau badan usaha, baik yang berbentuk badan hukum maupun bukan

\footnotetext{
${ }^{4}$ Salim,2014, Hukum Kontrak Teori \& Teknik Penyusunan Kontrak, Jakarta : Sinar Grafika, hlm.9-
} 


\title{
PATIK : JURNAL HUKUM Vol : 09 No. 2 April 2020, Hal 102 -113
}

berbadan hukum yang didirikan dan berkedudukan atau melakukan kegiatan dalam wilayah hukum Negara Republik Indonesia, baik sendiri maupun bersama-sama melalui perjanjian menyelenggarakan kegiatan usaha dalam bidang ekonomi.

\begin{abstract}
Metode
Penelitian yang akan dilakukan adalah penelitian hukum normatif. ${ }^{5}$. Tehnik analisa bahan hukum yang digunakan dalam penelitian ini merupakan langkah-langkah yang berkaitan dengan pengolahan bahan-bahan hukum yang dikumpulkan untuk meneliti permasalahan seperti yang terdapat dalam rumusan masalah. ${ }^{6}$ Tehnik yang digunakan adalah tehnik analaisis penalaran. Penalaran yang digunakan adalah penalaran induktif yaitu dengan melihat adanya fakta atau gejala yang ada dan kemudian mencoba untuk mengabstraksikan serta mencari prinsip-prinsip yang telah dikuasai untuk membangun suatu hipotesis. ${ }^{7}$ Setelah itu dilakukan interpretasi bahan hukum, kemudian dianalisis sehinggga akan memberikan solusi atas permasalahan dalam penelitian ini. Dalam penelitian ini metode analisis data yang digunakan adalah metode analisis deskriptif yaitu suatu penelitian yang dilakukan dengan tujuan utama untuk memberikan gambaran atau depenelitian tentang suatu keadaan secara objektif, dengan studi kepustakan dan menggunakan pendekatan perundang undangan. Dengan harapan dapat mengetahui bentuk hubungan hukum antara perusahaan transportasi online dengan driver online, Tanggung Jawab Hukum Perusahaan Transportasi Online Dan driver online Terhadap Pengguna Jasa Akibat Adanya Peralihan Kepemili kkan Akun
\end{abstract}

\section{Pembahasan Dan Hasil}

Diatur dalam pasal 1798 KUHPerdata dijelaskan bahwa pemberian kuasa adalah suatu perjanjian dengan mana seorang memberikan kekuasaan kepada seorang lain, yang menerimanya, untuk atas namanya menyelenggarakan suatu urusan. Bahwa perusahaan transportasi online tidak melakukan pemberian kuasa, karna pada umumnya pemberian kuasa berlaku pada pihak ketiga. Sistem dalam perusahaan transportasi online ini menganut sistem daftar langsung keperusahaan transportasi online dimana calon driver melakukan pendaftaran terlebih dahulu dengan membawa berkas-berkas yang diminta oleh perusahaan transportasi online sebagai persyaratan umum, sesudah itu pihak yang ingin menjadi driver online terdaftar dan memenuhi persyaratan maka pihak tersebut sudah resmi dinyatakan sebagai mitra kerja dengan ketentuan peraturan yang berlaku dalam perusahaan itu. Seluruh driver online yang sudah terdaftar sebagai mitra kerja diwajibkan untuk mengikuti kode etik yang sudah ditentukan oleh perusahaan transportasi online. Misalnya, harus ramah pada pelanggan, menjemput dan mengantarkan pelanggan sesuai dengan titik yang sudah ditentukan oleh pelanggan. Hal lain yang lebih serius driver online tidak diperboleh menjual akun dikarenakan perusahaan transportasi online tidak memperbolehkan akun beralih ke pihak lain tanpa ada persetujuan dari perusahaan transportasi online. Jika itu terjadi maka pihak perusahaan transportasi online langsung

\footnotetext{
${ }^{5}$ Penelitian hukum normatif atau penelitian perpustakaan ini merupakan penelitian yang mengkaji studi dokumen, yakni menggunakan berbagai data sekunder seperti peraturan perundang-undangan, keputusan pengadilan, teori hukum dan dapat berupa pendapat para sarjana.

6 Johny Ibrahim, Teori Dan Metedologi Penelitian Hukum Normatif, (Malang: Bayu Media Publishing, 2006), hlm.297

${ }^{7}$ Peter Mahmud, Penelitian Hmkum, (Jakarta: Kencana, 2006), hlm.43.
} 


\section{PATIK : JURNAL HUKUM Vol : 09 No. 2 April 2020, Hal 102 -113}

menindak lanjutin dengan memberikan sanksi berupa suspen atau penokaktifan akun tersebut. ${ }^{8}$

Bahwa berdasarkan dalam pasal 1601 a kitab Undang-undang KUHperdata perjanjian perburuhan adalah perjanjian dengan mana pihak yang satu, siburuh, mengikatkan dirinya untuk dibawah perintah pihak yang lain simajikan, untuk sesuatu waktu tertentu, melakukan pekerjaan dengan menerima upah. Masyarakat yang tinggal atau beraktivitas di perkotaan memang tak asing dengan fenomena maraknya transportasi online yang layanannya berbasis aplikasi seluler ini. Hampir diseluruh penjuru perkotaan ini dapat ditemui driver online yang lewat silih berganti membonceng pengguna jasanya. Apalagi didaerah padat lalu lintas seperti kota besar.

Pertumbuhan bisnis perusahaan transportasi online ini diikuti dengan makin meningkatnya masyarakat, terbukti dari terus bertambahnya jumlah pengunduh aplikasi tersebut. Masyarakat yang beranggapan bahwa para driver online itu mempunyai hubungan kerja dengan perusahaan transportasi online. Alasannya beragam. Mulai dari adanya kewajiban driver online "menjaminkan" surat berharga seperti ijazah saat awal mendaftar hingga masalah upah atau asuransi yang diberikan kepada driver online. Soal asuransi dan upah yang lazim dan semestinya diberikan kepada pekerja. untuk bicara dari sisi hukum, untuk melihat ada tidaknya hubungan kerja, tidak hanya bisa dilihat dari ada tidaknya kewajiban penitipan ijazah, upah dan asuransi seperti diatas. Menentukan ada tidaknya hubungan kerja ini penting agar kita bisa melihat apakah ada hubungan kerja, berarti tidak ada istilah pekerja dan pengusaha. Yang ada hanyalah mitra. Dikarenakan peraturan perundang-undangan dibidang ketenaga kerjaan mengatur mengenai hal- hal sehubungan dengan pekerja dan pengusaha. Berdasarkan penjelasan tersebut, hubungan hukum antara perusahaan transportasi online dengan driver online adalah hubungan kemitraan yang berdasarkan perjanjian kemitraan. Oleh karena itu, perlindungan hukum terhadap driver bukanlah perlindungan bagi pekerja berdasarkan perjanjian kerja, melainkan perlindungan sebagai pihak dalam sebuah perjanjian kemitraan.'

Perjanjian dikatakan sebagai salah satu sumber yang akan melahirkan suatu perikatan bagi para pihak yang melaksanakan dari suatu perjanjian. Dengan demikian dapat disimpulkan bahwa suatu perikatan merupakan perjanjian yang muncul dari suatu kesepakatan yang dibuat oleh para pihak baik secara bersama-sama maupun secara sepihak. Sebagaimana ditegaskan kembali dalam bunyi pasal 1313 kitab Undang-Undang Hukum Perdata yang menyebutkan bahwa perjanjian atau persetujuan adalah suatu perbuatan dengan mana satu orang atau lebih mengikatkan dirinya terhadap satu orang lain atau lebih. Sehingga jelas terlihat dari maksud yang terkandung pada bunyi pasal 1313 kitab Undang-Undang Hukum Perdata bahwa terjadinya perikatan dikarenakan telah diperolehnya izin atau kehendak dari mereka yang terikat dengan suatu perjanjian itu, yaitu mereka yang mangadakan kesepakatan atas perjanjian yang bersangkutan. Di dalam kitab Undang-Undang Hukum Perdata yang dibuat secara bersama oleh para pihak telah terjadi atau terlahir bilamana para pihak menyepakati perjanjian tersebut sehingga perjanjian yang telah disepakati tersebut telah memiliki akibat hukum. Sebagaimana yang tertuang dalam pasal 1320 KUHperdata mengenai salah satu unsur yakni sepakat. Kesepakatan yang dilakukan oleh para pihak untuk bersama-sama tunduk pada perjanjian.

\footnotetext{
${ }^{8}$ Hasil wawancara dengan Hisar, sebagai driver online dari perusahaan grab, mengenai pemberian kuasa Tanggal 20 maret 2020.

${ }^{9}$ Hukum online, perlindungan hukum bagi driver ojek online, https://m.hukumonline.com/klinik/detail/ulasan/lt5648cbcfc6ad2/perlindungan-hukum-bagi-idriver-i-ojekionline-i/. (diakses pada tanggal 19 Maret 2020 pukul 22:30 Wib).
} 


\section{PATIK : JURNAL HUKUM Vol : 09 No. 2 April 2020, Hal 102 -113}

Jika dilihat dari unsur perikatan yang muncul dari suatu perjanjian, maka dapat dikatakan bahwa driver online telah melakukan perikatan bersama dengan pihak perusahaan transportasi online, sebagaimana yang tercantum dalam pasal 1313 KUHPerdata yang menyebutkan bahwa perikatan lahir atau terjadi dikarenakan memperoleh izin atau kehendak dari pihak yang yang terikat dari perjanjian tersebut. Dengan adanya persetujuan atau kehendak dari para pihak maka telah terjadi hubungan hukum diantaran keduanya. Hal ini didasari dengan driver online melakukan pendaftaran kepada pihak perusahaan transportasi online sehingga secara otomatis telah terjadi perikatan secara hukum yang pastinya akan memunculkan kewajiban dan hak yang harus dipatuhi oleh kedua belah pihak. Sehingga mengenai hubungan kerja yang menyebutkan bahwa terdapat beberapa mengenai perintah kerja, klasifikasi pekerjaan dan pengupahan, mengenai ketiga hal unsur dalam hubungan kerja tidak memenuhi unsur-unsur yang terjadi pada perjanjian kemitraan antara perusahaan jasa transportasi online dan driver online tidak dapat tunduk kepada Undang-Undang No. 13 Tahun 2003 Tentang Ketenagakerjaan. Dikarenkan bahwa penerapan yang terjadi di dalam suatu perjanjian hubungan kerja di kedua pihak ialah perjanjian kemitraan atau perjanjian kerjasama.

Perjanjian kemitraan merupakan perjanjian yang memiliki hubungan kerja yang kedudukannya sama atau setara sebagai mitra atau rekan kerja serta kedudukan dalam hubungan pekerjaan memiliki keutamaan yang paling mendasar yakni saling menguntungkan di keduanya. Perjanjian kemitraan yang memiliki bentuk perjanjian bagi hasil, perjanjian keagenan, dan perjanjian sub-kontrak. Sehingga sesuai dengan isi dari perjanjian kemitraan bahwa perusahaan tranportasi online memposisikan pekerja atau driver online sebagai mitra kerja dalam menjalankan kegiatan transportasi.

Dengan demikian berdasarkan hubungan kerja terjadi sebagaimana yang termaksud dalam bunyi pasal diatas mengindikasi bahwa perjanjian yang berlaku ialah perjanjian kemitraan bukan perjanjian kerja sehingga dalam perjanjian kemitraan, perusahaan transportasi online memiliki kewenangan untuk membuat perjanjian dan membatalkan perjanjian dengan menggunakan standar operasional pekerjaan dan prosedur yang jelas kesalahan atau pengingkaran terhadap isi yang telah disetujui oleh kedua belah pihak. ${ }^{10}$

Bentuk dari perjanjian atas dasar kemitraan ini dapat berupa perjanjian bagi hasil, perjanjian keagenan, perjanjian sub-kontrak, perjanjian pembayaran (setoran), sejumlah nilai uang tertentu dan bentuk perjanjian lainnya. Perjanjian kemitraan yang dilakukan oleh driver online dengan dan perusahaan transportasi online berbentuk bagi hasil. Sistem bagi hasil yang diterapkan oleh perusahaan transportasi online dengan mitranya yaitu driver online menggunakan perbandingan presentasi tertentu untuk pembagian pendapatannya. Pendapatan langsung dipotong setelah driver online menyelesaikan tugasnya melalui sistem yang digunakan oleh perusahaan transportasi online. Jumlah pembagian keuntungan antara satu perusahaan transportasi online dengan perusahaan lainnya berbeda-berbeda presentasenya, seperti PT Go-Jek menggunakan presentasi keuntungan 20\% untuk perusahaan dan $80 \%$ untuk drivernya. ${ }^{11}$ Perusahaan Grab Indonesia menetapkan pambagian sistem bagi hasil yang lebih besar untuk drivernya yaitu $90 \%$ untuk driver dan $10 \%$ untuk perusahaan untuk jarak dekat serta $85 \%$ untuk driver dan

${ }^{10}$ Undiksha, Penerapan perjanjian dalam hubungan kerja dan pelindungan hukum bagi driver online, https://scholar.google.co.id/scholar?hl=id\&as $\mathrm{sdt}=0 \% 2 \mathrm{C} 5 \& \mathrm{q}=\mathrm{jurnal}++$ perjanjian + kemitraan + mngena $\mathrm{i}+$ perusahaan + transportasi + online + dengan + driver + online $\& b \operatorname{btnG}=\# \mathrm{~d}=\mathrm{gs}$ qabs\&u $=\% 23 \mathrm{p} \% 3 \mathrm{DKOQn} 52 \mathrm{KF}$ rk J. (diakses pada tanggal 20 Maret 2020 pukul 09:11 Wib)

${ }^{11}$ Hasil Wawancara dengan toby, sebagai driver online dari perusahaan PT Go-Jek, hubungan bagi hasil, Tanggal 20 Maret 2020. 


\section{PATIK : JURNAL HUKUM Vol : 09 No. 2 April 2020, Hal 102 -113}

$15 \%$ untuk perusahaan jarak jauh. ${ }^{12}$ Selain itu perusahaan transportasi online juga menerapkan sistem bonus kepada drivernya apabila dalam satu hari driver tersebut telah mengangkut pengguna jasa/penumpang sejumlah target tertentu. Jadi dalam hal ini pendapatan driver bergantung pada seberapa banyak penumpang yang melakukan pemesanan melalui aplikasi dan kesediaan driver untuk menyalurkan jasa sesuai permintaan penumpang.

Tanggung jawab hukum perusahaan penyedia aplikasi transportasi online, dapat diketahui dengan memahami bahwa usaha melalui teknologi aplikasi bukan merupakan klasifikasi dari bidang usaha, dalam hal ini perusahaan penyedia aplikasi transportasi onlne berfungsi sebagai penghubung kegiatan usaha, dan bukan merupakan bidang usaha yang ada secara khusus. Karena pada dasarnya perusahaan penyedia aplikasi transportasi online bukan merupakan perusahaan transportasi online seperti perusahaan penyedia taksi atau bus umum maka tanggung jawab perusahaan penyedia aplikasi transportasi online tidak sama seperti tanggung jawab perusahaan penyedia transportasi umumnya. Tanggung jawab dari perusahaan transportasi online kepada pengguna jasa akibat adanya peralihan akun dan mengalami kerugian. hal tersebut dikarenakan tanggung jawab perusahaan aplikasi transportasi online menganut prinsip tanggung jawab terbatas (limitation of liabilityprin ciple), karena dalam hal ini pada pelaksanaan tanggung jawab perusahaan terdapat limit tertentu sebagai batas maksimal tanggung jawab perusahaan transportasi online untuk membayar ganti rugi. Dari sisi perusahaan penyedia aplikasi transportasi online meskipun tanggung jawab mereka terbatas terhadap pengguna jasa transportasi online yang dijalankan, namun pada dasarnya citra perusahaan sangat dipengaruhi dengan pelaksanaan dari jasa transportasi itu sendiri. Apabila pelaksanaan transportasi buruk maka citra perusahaan transportasi online juga akan terkena imbasnya, jadi bukan hanya mitra/driver yang terkena dampak dari pelaksanaan transportasi yang buruk.

Walaupun bentuk dari perusahaan transportasi online merupakan perusahaan teknologi namun perusahaan penyedia aplikasi transportasi online tetap memiliki tanggung jawab terhadap pengguna jasa jika pengguna jasa dirugikan akibat peralihan akun yang menggunakan aplikasi perusahaan penyedia aplikasi transportasi online tersebut. Hal ini dikarenakan kesepakatan pengguna jasa dan pemberi jasa atau driver online terjadi didalam aplikasi buatan perusahaan transpotasi online tersebut, sehingga sebagai penghubung antara pengguna jasa dan driver online, perusahaan penyedia aplikasi transportasi online juga bertanggung jawab atas terlaksananya pelayanan yang dilakukan pihak driver online.

Jadi walaupun driver online merupakan pemberi layanan yang seharusnya bertanggung jawab atas keselamatan dan keamanan konsumen (pengguna jasa), namun pada dasarnya perusahaan penyedia aplikasi transportasi online juga harus ikut bertanggung jawab karena dalam hal ini sistem yang dijalan oleh driver online merupakan produk perusahaan penyedia aplikasi transportasi online tersebut, karena adanya hubungan kemitraan antara perusahaan penyedia aplikasi transportasi online dengan driver online maka jika terjadi kerugian terhadap pengguna jasa kedua belah pihak memiliki tanggung jawab yang sama terhadap pengguna jasa ( konsumen) yang dirugikan itu. Pasal 28 huruf c Peraturan Menteri Perhubungan Republik indonesia Nomor PM 118 Tahun 2018 Tentang penyelenggaraan Angkutan Sewa Khusus menyebutkan bahwa perusahaan penyedia aplikasi memiliki kewajiban untuk memberikan perlindungan pada konsumennya sesuai dengan perundang-undangan. selaku pelaku usaha, pengusaha penyedia aplikasi sebagai penyedia layanan jasa dalam menjalankan kewajibannya wajib melaksanakan hak-hak

${ }^{12}$ Hasil Wawancara dengan hisar, sebagai driver online dari perusahan Grab, Hubungan bagi hasil, tanggal 20 Maret 2020. 


\section{PATIK : JURNAL HUKUM Vol : 09 No. 2 April 2020, Hal 102 -113}

penumpang sebagai konsumen. Berdasarkan pasal 4 UU No.8 Tahun 1999 Tentang perlindungan konsumen bahwa konsumen, memiliki hak untuk memperoleh kenyaman,keamanan,dan keselamatan dalam mengkonsumsi barang dan/atau jasa serta memiliki hak untuk mendapat kompensasi, ganti rugi dan/atau pengganti, apabila barang dan/atau jasa yang diterima tidak sesuai dengan perjanjian atau tidak sebagaimana mestinya, jadi dalam hal ini pelaku usaha wajib memenuhi hak konsumen tersebut dengan memberikan pelayanan produk atau jasa dengan baik dan benar, jika kewajiban tersebut tidak dipenuhi maka pelaku usaha wajib bertanggung jawab atas tidak terpenuhinya kewajiban tersebut dengan memberikan kompensasi atau ganti rugi terhadap konsumen.

Pada pasal 19 UU No. 8 Tahun 1999 Tentang perlindungan konsumen diatur mengenai kewajiban pelaku usaha untuk bertanggung jawab atas adanya kerusakan, pencemaran atau kerugian konsumen akibat mengonsumsi atau menggunakan barang atau jasa yang dihasilkan atau diperdagangkan oleh pelaku usaha, pemberian kompensasi atau ganti rugi yang dapat diberikan oleh pelaku usaha dapat berupa pengembalian uang, penggantian barang atau jasa yang sejenis atau setara nilainya, perawatan kesehatan dan pemberian santunan yang sesuai dengan ketentuan peraturan perundang-undangan yang berlaku. $^{13}$

Tanggung jawab yaitu suatu perbuatan untuk siap menanggung segala sesuatu hal yang muncul sebagai akibat dari dilakukannya suatu aktivitas tertentu. Mengenai tanggung jawab maka tentu tidak akan lepas dari suatu kewajiban yang harus dipenuhi karena ada hak yang harus dipenuhi. Maka driver online adalah pihak yang akan bertanggung jawab atas adanya peralihan akun driver online terhadap pengguna jasa. Driver online adalah pihak yang bertanggung jawab, karena driver online adalah pihak yang bertugas secara langsung kepada pengguna jasa. jika pada saat pengguna jasa menggunakan jasa dari driver online dan terjadi kecelakaan, maka terdapat unsur hak yang tidak terpenuhi yaitu menjaga keamanan dan keselamatan dari pengguna jasa. Peralihan akun driver online yang mengakibatkan orang yang tidak bertanggung jawab dapat menyalahgunakan akun driver online untuk digunakan sebagai sarana dalam melakukan kejahatan. Pada keadaan tersebut pengguna jasa sebagai konsumen merupakan pihak yang lemah yang menjadi korban atas adanya penyalahgunaan akun tersebut.

Berkaitan dengan prinsip tersebut tanggung jawab pengangkut atau driver online dalam transportasi online menganut prinsip tanggung jawab berdasarkan unsur kesalahan ( fault liability/liability based on fault) dan prinsip tanggung jawab praduga untuk selalu bertanggung jawab ( presumption of liability principle). Hal ini dikarenakan pengangkut atau driver online bertanggung jawab atas kerugian yang timbul dalam penyelenggaraan pengangkut, tetap jika driver online berhasil membuktikan bahwa dia tidak bersalah atau lalai maka driver online atau pengangkut dapat dibebaskan dari tanggung jawab.

Jika perbuatan driver online sangat merugikan pihak pengguna jasa, maka tersebut dapat dikategorikan dalam perbuatan melawan hukum yang diatur dalam pasal 1365 KUHperdata yang disebutkan bahwa "tiap perbuatan melawan hukum yang membawa kerugian kepada orang lain, mewajiban orang karena salahnya menerbitkan itu, mengganti kerugian tersebut. ${ }^{14}$

Jika kedua belah pihak yang berseteru ingin mengadakan musyawarah, dapat memilih lewat beberapa opsi. Driver online dapat melakukan musyawarah dengan pengguna jasa dengan cara melalui jalur non litigasi seperti: negosiasi, mediasi, konsilisasi, dan arbitrase.

\footnotetext{
${ }^{13}$ Nuraini, tanggung jawab perusahaan transportasi online terhadap penumpang akibat adanya peralihan akun driver, https://e-journal.unair.ac.id/JD/article/download/14499/8023 . (diakses pada tanggal 20 Maret 2020 pukul 10:59 Wib).

${ }^{14}$ Subekti, Tjitrosudibio, op.cit, hlm.346.
} 


\section{Kesimpulan dan Saran}

Bentuk hubungan hukum antara perusahaan transportasi online dengan driver online, menurut KUHPerdata, yaitu dikarenakan adanya perjanjian kemitraan dalam kedua belah pihak. Maka dalam pasal 1313 kitab Undang-Undang Hukum Perdata bahwa terjadinya perikatan dikarenakan telah diperolehnya izin atau kehendak dari mereka yang terikat dengan suatu perjanjian itu, yaitu mereka yang mangadakan kesepakatan atas perjanjian yang bersangkutan. Di dalam kitab Undang-Undang Hukum Perdata yang dibuat secara bersama oleh para pihak telah terjadi atau terlahir bilamana para pihak menyepakati perjanjian tersebut sehingga perjanjian yang telah disepakati tersebut telah memiliki akibat hukum. Sebagaimana yang tertuang dalam pasal 1320 KUHperdata mengenai salah satu unsur yakni sepakat. Kesepakatan yang dilakukan oleh para pihak untuk bersama-sama tunduk pada perjanjian. Dalam perjanjian kemitraan antara perusahaan transportasi online dan driver online dimana kedua belah pihak mempunyai hak dan kewajiban dalam perjanjian kemitraan. Perjanjian kemitraan yang dilakukan oleh driver online dengan perusahaan transportasi online berbentuk bagi hasil. Sistem bagi hasil yang diterapkan oleh perusahaan transportasi online dengan mitranya yaitu driver online menggunakan perbandingan presentasi tertentu untuk pembagian pendapatannya. Pendapatan langsung dipotong setelah driver online menyelesaikan tugasnya melalui sistem yang digunakan oleh perusahaan transportasi online. Jumlah pembagian keuntungan antara satu perusahaan transportasi online dengan perusahaan lainnya berbeda-berbeda presentasenya, seperti PT Go-Jek menggunakan presentasi keuntungan 20\% untuk perusahaan dan $80 \%$ untuk drivernya. Perusahaan Grab Indonesia menetapkan pambagian sistem bagi hasil yang lebih besar untuk drivernya yaitu $90 \%$ untuk driver dan $10 \%$ untuk perusahaan untuk jarak dekat serta $85 \%$ untuk driver dan $15 \%$ untuk perusahaan jarak jauh.

Tanggung jawab perusahaan transportasi online, dan driver online terhadap pengguna jasa akibat adanya peralihan kepemilikan akun, karena adanya hubungan kemitraan antara perusahaan dengan driver online maka jika terjadi kerugian terhadap pengguna jasa kedua belak pihak memiliki tanggung jawab yang sama terhadap pengguna jasa (konsumen) yang dirugikan akibat adanya peralihan kepemilikan akun, pada pasal 19 UU No. 8 Tahun 1999 Tentang Perlindungan Konsumen. Dan driver online juga dapat diminta pertanggung jawaban jika merugikan pihak pengguna jasa dikarenakan akibat perbuatannya dalam memperalihkan akun kepemilikkannya tersebut dikategorikan dalam perbuatannya melawan hukum yang diatur dalam pasal 1365 KUHperdata, dan driver online dapat melakukan penyelesaiaan permasalahan dengan melalui jalur non litigasi seperti negosiasi, mediasi, konsilisasi, dan arbitrase. Kepada pengguna jasa, sebaiknya lebih baik hati-hati dalam memilih pengemudi driver online. Apabila depenelitian motor, mobil dan identitas driver online berbeda dengan aplikasi transportasi online, maka sebaiknya pesanan dibatalkan dan tidak usah naik.

\section{DAFTAR PUSTAKA}

\section{Buku}

Abdulkadir,Muhammad. 2010. Hukum perdata indonesia. Bandung PT Citra Aditya Budi Santoso, Totok dan Nuritmo. Bank dan Lembaga Kaeuangan Lain. Penerbit Salemba Empat. Jakarta. 2014.

Peter. 2005. Penelitian hukum, Jakarta: Prenadamedia Group.

Soersono,2010. Perjanjian Dibawah Tangan, Jakarta : Sinar Grafika. 
PATIK : JURNAL HUKUM Vol : 09 No. 2 April 2020, Hal 102 -113

Salim. 2014. Hukum Kontrak Teori \& Teknik Penyusunan Kontrak, Jakarta : Sinar Grafika. Subekti. 2014. Aneka Perjanjian, Bandung : PT Citra Aditya Bakti.

Subekti,Tjitrosudibio. Kitab Undang-Undang Hukum Perdata, Jakarta : PT.Balai Pustaka.

\section{Peraturan Perundang-Undangan}

Undang-Undang Republik Indonesia Nomor 19 Tahun 2016 Tentang ITE

Undang-Undang Republik Indonesia Nomor 22 Tahun 2009 Tentang Lalu Lintasan dan Angkutan Jalan

Undang-Undang Republik Indonesia Nomor 8 Tahun 1999 Tentang Perlindungan Konsumen

\section{Website dan Jurnal}

Anam, Perlindungan Konsumen Terhadap Praktik Jual-Beli Akun Pengemudi Ojek

Online.https://scholar.google.co.id/scholar?start=10\&q=dalam + perjanjian + kemitraan + antara + perusahaan + dan + driver + online + tercipta + adanya + hak + dan + kewajiban $\& h l=\mathrm{i}$ d\&as $s d t=0,5 \# d=g s$ qabs\&u=\%23p\%3DZJGSFxoYYzcJ. (diakses pada tanggal 25 September 2020 pukul 10:48 Wib).

Grab, 2012. Perusahaan. https://id.m.wikipedia.org./wiki/grab_(perusahaan). (diakses pada tanggal 31 februari 2020 pada pukul 20:15 Wib)

Anggusti, M., \& Anggusti, Y. (2020). PENEGAKAN HUKUM DI INDONESIA DALAM RANGKA TATA KELOLA PEMERINTAHAN YANG LEBIH BAIK MENUJU 100 TAHUN KEMERDEKAAN INDONESIA (2045). Nommensen Journal of Legal Opinion, 1(01), 38-52. https://doi.org/10.51622/njlo.v1i01.37

Hukum online, perlindungan hukum bagi driver ojek online, https://m.hukumonline.com/klinik/detail/ulasan/lt5648cbcfc6ad2/perlindunganhukum-bagi-idriver-i-ojek-ionline-i/. (diakses pada tanggal 19 September 2020 pukul 22:30 Wib).

indriver, 2020. Aplikasi indriver. http://www.covesia.com/news/baca/8971/indriveraplikasi-transportasi-online-baru-hadir-di-padang. (diakses pada tanggal 01 september 2020 pada pukul 22:00 Wib).

Nuraini, tanggung jawab perusahaan transportasi online terhadap penumpang akibat adanya peralihan akun driver, https://ejournal.unair.ac.id/JD/article/download/14499/8023. (diakses pada tanggal 20 September 2020 pukul 10:59 Wib).

Tribunnews,metropolitan, 2018. Marak Jual Beli Akun Ojek Online, Go- Jek Ditawar RP 1,5 Juta. https://www.tribunnews.com/metropolitan/2018/03/13/marak-jual-beliakun-ojek-online-satu-akun-go-jek-ditawar-rp-15-juta?page=all. (diakses pada 11Februari 2020, Pada Pukul 21:30 Wib).

Undiksha,Penerapan Perjanjian dalam hubungan kerja dan pelindungan hukum bagidriveronline, https://scholar.google.co.id/scholar?hl=id\&assdt $=0 \% 2 \mathrm{C} 5 \& \mathrm{q}=\mathrm{jurnal}$ ++ perjanjian + kemitraan + mngenai + perusahaan + transportas $i+$ online + dengan + driver + online $\&$ btnG $=\# \mathrm{~d}=$ gsqabs\&u=\%23p\%3DKOQn52KFrkJ. (diakses pada tanggal 20 September 2020 pukul 09:11 Wib). 